\title{
OPENING OF GRAVES
}

\section{IN THE CEMETERY OF THE WIELBARK CULTURE IN KOWALEWKO.}

\author{
A PRELIMINARY ANALYSIS
}

\begin{abstract}
The paper discusses a practice of opening of graves which were recorded in the Wielbark Culture cemetery in Kowalewko. Proposals of interpretation which have been suggested so far were discussed and a new approach to the issue was put forward. It was debated to what extent archaeology would be able to answer a question of who and when disturbed graves. Furthermore, potential reasons behind the removal of artefacts which were deposited into the grave in the course of funeral rites were pointed out. This issue still requires further studies and a comparison against a broader cultural background.
\end{abstract}

Keywords: Roman Period, Wielbark Culture, grave opening, ,robbery” of cemeteries, atypical burials, fear of the dead

A phenomenon of opening - or, as it is more often said, also suggesting the nature of action - „robbery” of graves of the Wielbark Culture ${ }^{1}$ is commonly known. It is manifested by attention paid to this issue in scholarly literature $^{2}$. The problem is dealt with not only while discussing individual cemeteries ${ }^{3}$ or regions $s^{4}$, but also in a broader or more general manner ${ }^{5}$. It can be certainly said that this issue has not been examined in a satisfactory manner. This may result from objective difficulties, such as only partial examination of cemeteries with excavations, or the very nature of disturbance of graves, which is diverse and difficult to assess. The latter phenomenon is also possibly related to complex funeral rites of the Wielbark Culture ${ }^{6}$.

It has been noted that an intensification of the practice of grave opening in the Wielbark Culture concerns Phases

* Institute of Archaeology and Ethnology of the Polish Academy of Sciences, Łódź, kalina.skora@tlen.pl

1 The paper was prepared as part of completion of a research project of the National Science Centre (NCN, 2017/01/X/ HS3/00193) - Robbery or ritual? A phenomenon of opening of graves in the Wielbark Culture. An example of the cemetery in Czarnówko in Pomerania.

2 Cf. remarks of Mączyńska 2011, 244.

3 E.g., Pietrzak 1997; Schuster 2014, 63-66.

4 Żychliński 2015.

5 Tempelmann-Mączyńska 1989; Tempelmann-Mączyńska 1992; Schuster 2010, 255-258.

6 E.g., Andrzejowski et al. 2002; Skóra 2015b. On the example of the Masłomęcz Group - cf., e.g., Kokowski 2007, 132-141.
$\mathrm{B} 2 \mathrm{c}$ and $\mathrm{B} 2 / \mathrm{C1}^{7}$ (Table 1). This could be hypothetically and tentatively considered a resultant of a habit of more abundant grave furnishings. Such an assumption implies further logical consequences - a selection of burials and narrowing down the choice to such ones in which the dead were provided with rich grave goods. This would mean a good knowledge of the situation in the cemetery. Therefore, a conclusion can be drawn that these actions were undertaken by contemporary people.

It must be remembered here that conclusions on grave disturbances in the Wielbark Culture are drawn on the basis of analyses of inhumation burials. There is strong evidence that cremation burials were also subject to such actions. This was clearly and convincingly stated by M. Mączyńska in her monograph on a deposit of metal artefacts from Łubiana, Kościerzyna District ${ }^{8}$.

It is not easy to precisely define the time of grave opening and the sequence of post-funeral actions ${ }^{9}$. Concerning the Wielbark Culture, there are premises which

7 Schuster 2010, 255, Fig. 106.

8 Mączyńska 2011, 243-252.

9 Such a clarity concerning the situation and time can be seen in grave disturbances, e.g., in some Langobard cemeteries. For some burials it is assumed that the dead were deprived of their grave goods a few days after the burial. In some particular cases it is proved that the grave pit was opened twice - soon after the burial ceremony and after a longer time after that - Vaday 2015, 228. 
allow for an assumption that interferences took place when the body was still preserved to a degree which enabled it to be entirely moved within the grave pit, for instance, to a sitting position ${ }^{10}$. This, however, does not directly point to originators of such actions, due to the lack of knowledge of the time of body decomposition. On the other hand, it does not exclude communities using a given necropolis as potential suspects.

One of cemeteries of the Wielbark Culture where the practice of grave opening is manifested according to the chronology suggested by J. Schuster is Kowalewko in Greater Poland (cf. Table 1). Finds from this site can offer grounds to discuss the practice of grave opening in the Early and Middle Roman Period. This is because the site was fully examined with excavations and the state of preservation of skeletons is good.

This paper will not clarify all doubts related to the issue mentioned in the title. It is merely an attempt at drawing attention to some of its aspects. This is relevant for assessing an intention behind grave opening, which can be expressed with the following questions: who, when, and how?

Concerning finds of the Wielbark Culture, the following terms are commonly used to discuss the phenomenon mentioned in the title of this paper: robbery, robbing or plundering. At the same time, using these terms also means an interpretation of the sense of these actions. This means that economic motivations and acquisition of artefacts are seen as the main reason. „Disturbance” or „opening” is semantically neutral - these are inseparably used with the term „secondary”. Moreover, „emptying of a grave” falls between „opening” and „plundering” with regard to its significance. In this place it must be said that the term „grave opening" seems to be more proper for the first intrusion into the grave, that is, an undertaking which ends with the burial ceremony. On the other hand, „secondary” opening should be reserved for cases when the grave is opened for the second and subsequent time. Furthermore, terms „,intrusions” or „manipulations” do not bear an interpretational load, either ${ }^{11}$.

\section{Previous opinions on the issue of grave opening at Kowalewko}

Opinions on a robbery nature of grave disturbance in the Wielbark Culture are generally expressed on the basis of what is clearly noticeable. This means that of key importance are trenches leading to the level of the skeleton and the lack or abandonment of individual grave goods in the trench. Furthermore, a disturbance of the anatomical arrangement of the skeleton, and sometimes also the lack of its individual parts, are considered evidence for such actions.

10 Skóra 2017.

11 A similar inaccuracy can be seen in the English term ,reopen” or the German „Wiederöffnung”. Cf. also Kümmel 2009.

\begin{tabular}{|c|c|c|c|}
\hline Cemetery & \multicolumn{3}{|c|}{ N of opened graves } \\
\hline & $\begin{array}{c}\text { Roman } \\
\text { Period }\end{array}$ & B2a-b & B2c-C1 \\
\hline Grzybnica & 2 & 1 & 2 \\
\hline Pruszcz Gdański, Site 10 & 16 & 1 & 18 \\
\hline Ulkowy & 1 & - & 1 \\
\hline Kowalewko & 10 & 6 & 20 \\
\hline
\end{tabular}

Table 1. Selected cemeteries of the Wielbark Culture with traces of grave opening and their dating. After Schuster 2010, Abb. 106.

In his monograph on the cemetery in Kowalewko and in separate papers ${ }^{12} \mathrm{~T}$. Skorupka underlined a robbery aim of revealed disturbances. At the same time, this researcher stressed that although the main focus of the „robbers” were material goods, they did not ignore post-mortem remains of the dead. Therefore, attention was focused on features in which one can see practices aimed at „neutralisation” of the power of the dead or protection against their revenge. Such practices chiefly concerned skulls of deceased persons ${ }^{13}$.

Daniel Żychliński was of a different opinion concerning reasons behind grave opening in the Roman Period in Greater Poland. He has recently proposed a daring theory saying that human bones, wish special reference to pelvis, were robbed for commercial purposes ${ }^{14}$. According to this scholar, out of 39 burials from Kowalewko where traces of intrusions were found, it was only in three cases that only grave goods were robbed. In seven cases artefacts and parts of the skeleton were robbed, and in the remaining ones we are dealing with bones robbery ${ }^{15}$. The same researcher also considered a possibility of extraction of bone remains for the purpose of endocannibalism, or ritual consumption of bones of ancestors ${ }^{16}$. These theories are as interesting as controversial.

\section{How many graves were opened?}

In the cemetery in Kowalewko T. Skorupka identified 39 inhumation graves as „robbed” or „disturbed”17, which is $7.9 \%$ of the total number of discovered features $(n=496)$. No traces of this kind were recorded in cremation graves, and the very possibility of „robberies” was considered by this researcher acceptable, but „extremely improbable”18. With regard to some inhumation burials, such actions were seen as possible, but not without doubts. This results from

12 Skorupka 2000; Skorupka 2001; Skorupka 2008.

13 Skorupka 2000; Skorupka 2008, 83.

14 Żychliński 2015.

15 The same reasons were supposed to have motivated persons who disturbed burials at Słopanowo, Szamotuły District, Graves 5, 6, 27 (?) and 43, as well as at Przebędowo, Poznań District (Żychliński 2015, Table 1).

16 Żychliński 2014, 94-95; Żychliński 2015.

17 Skorupka 2001, 214.

18 Skorupka 2001, note 45. 


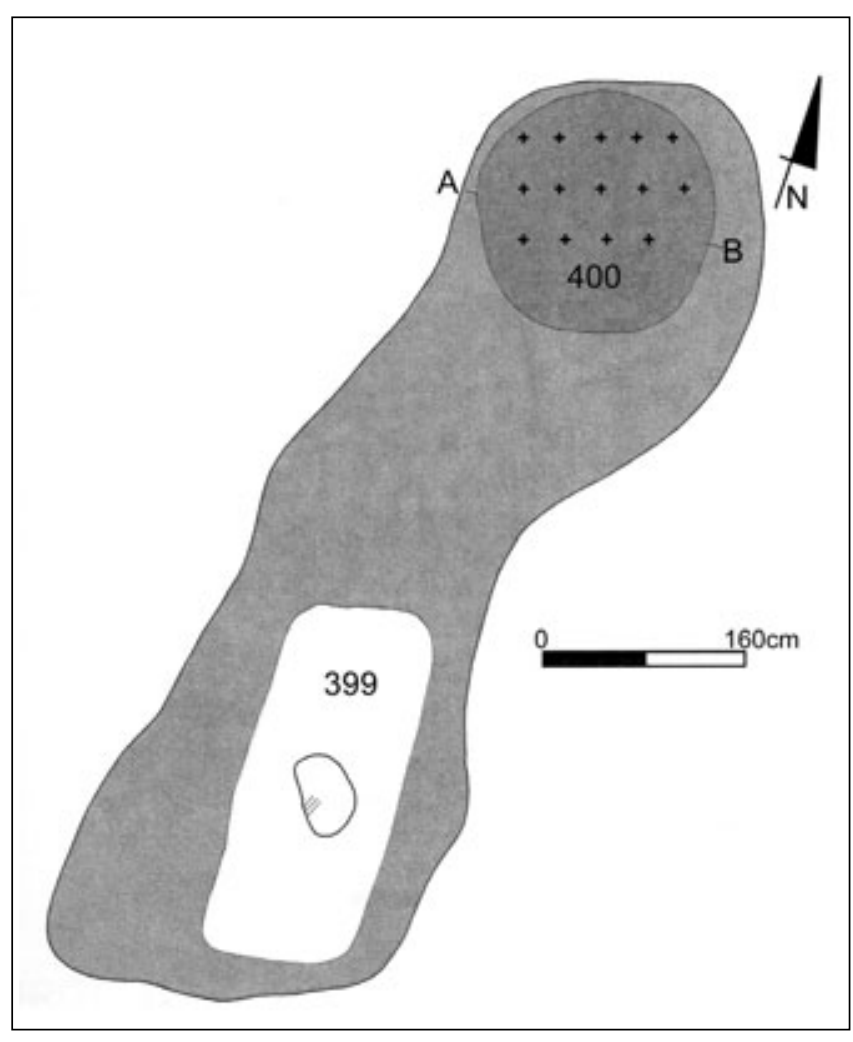

Fig. 1. Cut through Graves 399 and 400 - result of robbers getting acquainted with the cemetery (?). After Skorupka 2001.

the fact that due to, among others, given soil conditions in the course of excavations, no trenches which intruded into grave pits were recorded in graves. In many cases the assessment was based on the arrangement of bone remains and the position of parts of dress not in accordance with the anatomical arrangement. Furthermore, artefacts which were part of grave furnishings were discovered at various levels above the skeleton (Graves 353 and 357).

Examining the situation within grave pits, first of all taking the integrity and anatomical arrangement of the skeleton into consideration, allows for identification of other graves which were subject to the discussed practice. Such actions are not isolated, as certain situations become clear only after the completion of research ${ }^{19}$.

It is possible that the group of previously identified features may be completed with:

- pits in which no bones were found. This could demonstrate that they were thrown outside in the course of „robbery", when the pit was entirely open. Of course such a theory should be verified due to imperceptibility of trenches, by means of rejection of original reasons behind such a shape of the grave. The following reasons should be considered: the lack of burial from the very beginning, a symbolic nature of the grave ${ }^{20}$, or a complete decomposition of bones in unfavourable conditions of deposition.

\footnotetext{
19 Cf., e.g., Aspöck 2015, 34.

20 Cf. Kümmel 2009, 142.
}

- pits in which the intrusion is „punctual,” which is concluded on the basis of bone arrangement. Of course in this case it is essential to take into consideration other reasons behind the absence of bones (e.g., skull or lower limbs) or their translocation. Dislocation of bones can also result from the process of body decomposition, activities of animals, agricultural works in the case of shallowly deposited burials, etc. ${ }^{21}$.

\section{Methods \\ Reconnaissance cut}

In the interpretation of T. Skorupka, a feature recorded in the south-eastern zone of the cemetery is a trace of reconnaissance „robbery” actions. An about $7 \mathrm{~m}$ long and about 2-2.5 m wide pit is considered evidence that robbers were getting acquainted with the funeral ritual. Knowledge on the rules of furnishing the dead with grave goods was acquired by means of reaching the first inhumation grave and the first cremation one ${ }^{22}$ (Fig. 1).

Similar cuts which destroyed a few burials are known from cemeteries from other regions of Europe, e.g., from the cemetery in Madaras, which is dated to the Migration Period ${ }^{23}$ (Fig. 2). „Testing” pits are also revealed, e.g., in Merovingian cemeteries ${ }^{24}$.

\section{„Robbery” trenches}

As it has already been stated, pits whose fill was similar to that of grave pits were not recorded. Their position is evidenced by a disturbed arrangement of bones and artefacts found above the level of the skeleton. On the other hand, we do not know anything on failed attempts at selecting graves and imprecisely led „shafts”.

The lack of differences between fills of grave pits and fills of trenches is sometimes considered a proof that trenches were backfilled immediately after the intrusion, using soil which was previously removed from them. This could imply a need for, e.g., obliterating the traces. On the basis of the structure of trench fills it is sometimes noticed that the trenches were left open and their backfilling took place in a natural manner ${ }^{25}$. Furthermore, a homogeneous nature of layers in pits and trenches may demonstrate a short period of time which elapsed between the cessation of use of the cemetery and the entry of robbers (one can possibly consider an incessant use of the necropolis) ${ }^{26}$ (Fig. 3).

21 Kümmel 2009, 142.

22 Skorupka 2008, 83.

${ }^{23}$ Köhegyi 1980, Figs. 4-6.

24 E.g., Sikora and Bofinger 2009, 340

25 Cf. Aspöck 2011, 302. Such cases are recorded in the Wielbark Culture cemetery in Czarnówko, Lębork District - the author's own observation and kind information from Maciej Marczewski, MA.

${ }^{26}$ Such a possibility was also taken into consideration by T. Skorupka 2008, 83. 


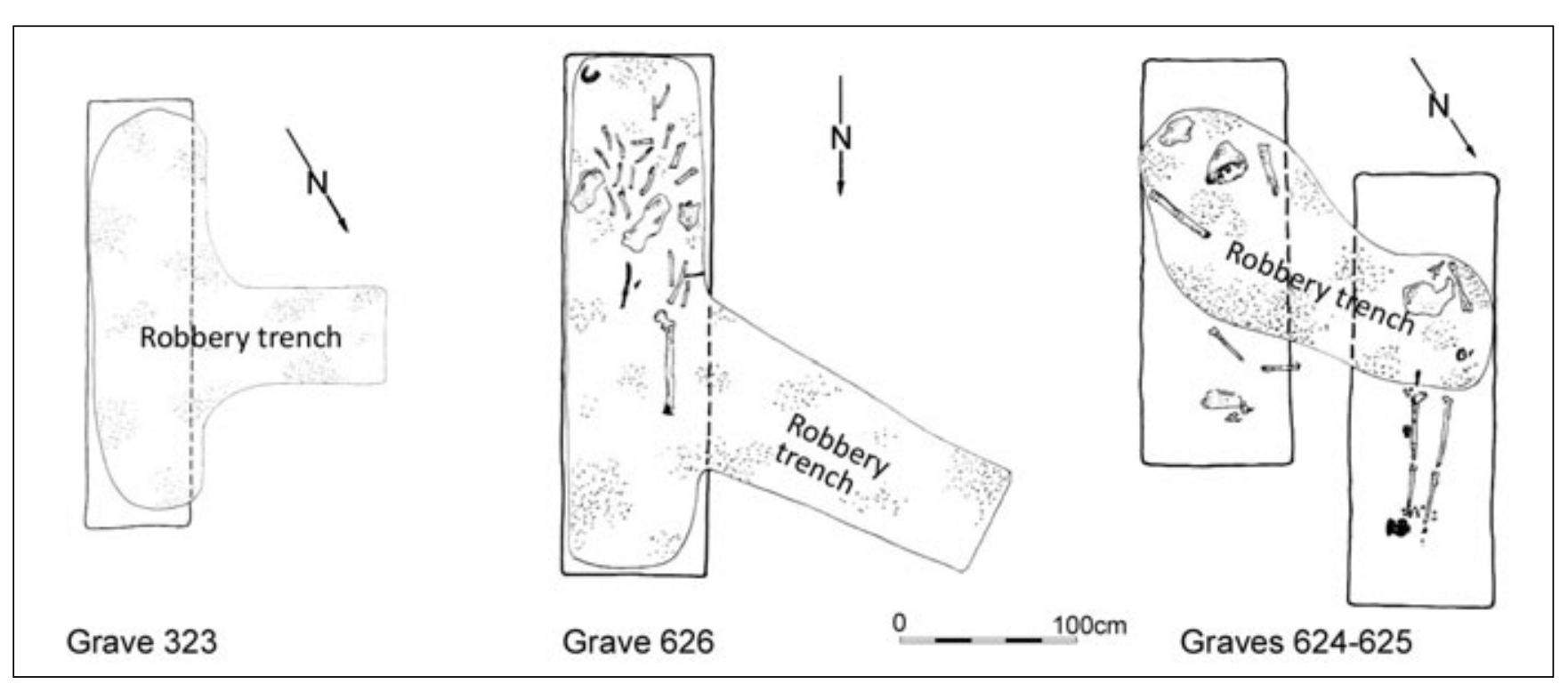

Fig. 2. Examples of cuts which ,identified” burials from the cemetery in Madaras, Bács-Kiskun District. After Köhegyi 1980.

\begin{tabular}{|c|c|c|c|c|c|}
\hline \multicolumn{6}{|c|}{ DisTURBED ZONE OF THE GRAVE PIT } \\
\hline NORTHERN & Central & SOUTHERN & EASTERN-CENTRAL & WESTERn-CENTRAL & ENTIRE SuRfaCe \\
\hline $\begin{array}{c}109,167,168,188, \\
190,224,226,236, \\
237,284,327,332, \\
349,357,359,361, \\
374,376,386,413, \\
453,477,483\end{array}$ & 227, 334 & & $345,353,379,432$ & & $\begin{array}{c}98 \text { (?), 100, 112, } \\
213,280 \text { (?), } \\
362 \text { (?), } 391 \text { (?), } \\
404 \text { (?), } 399 / 400\end{array}$ \\
\hline $\begin{array}{l}169,184,197,223 \\
233,291,366,492\end{array}$ & $\begin{array}{c}189 \text { (?), } 216 \text { (?), } \\
320 \text { (?), }\end{array}$ & $\begin{array}{c}60,69,244,254, \\
262,272,417 \\
421,452,470\end{array}$ & $\begin{array}{c}62,170,166,257 \\
292,331,338,387 \\
419,420,476\end{array}$ & 220,382 & \\
\hline
\end{tabular}

Table 2. Kowalewko. List of graves with disturbed pit zones of inhumation graves. Based on T. Skorupka 2001. New proposals are given in italics.

One can expect fills of „robbery” trenches to be different from surrounding pits in such places where the opening of a grave occurred when new layers appeared above the usage level of the cemetery. These layers were related to a continuation of settlement in this area. It was only thereafter that „robbers” came into action.

At Kowalewko, diameters of trenches are usually not measured. We do not know whether trenches always reached the level of the skeleton, either. It was only sporadically that it was possible to record their approximate measurements (e.g., Grave 349 - an oval trench with the size of 140x85 cm). It is also known that they encompassed only selected parts of grave pits, especially their northern zones (Table 2).

It is only in some cases that one can assume that the pit was disturbed in its entire surface. Such actions can be assumed in case the skeleton is entirely absent or its parts are scattered over the entire bottom of the pit. This group includes, among others, two burials located under earthworks (Graves 100 and 112 - Fig. 4). Such intensified interest in the entire grave pit could suggest that „robbers” expected to find extraordinarily rich grave furnishings.
It cannot be denied that „robbers” made use of rational methods of work - they attempted at reaching grave contents as quickly as possible and with the lowest workload. Therefore, as far as it was possible, diameters of trenches which were round or oval in cross-section were reduced to a necessary minimum. Such a „luxury” could be afforded only in cases of burials deposited in coffins, whose state of preservation allowed to plunder their interiors using hook-like tools. Damage or collapse of the upper part of the body container excluded the use of this method. In such a situation or in cases where bodies were deposited directly into the ground one can rather expect shafts with larger diameters. Such shafts would encompass larger parts of grave pits, but they would concentrate around upper parts of skeletons. According to M. Köhegyi, taking findings from Sarmatian cemeteries into consideration, it can be assumed that their diameters could be at least $1 \mathrm{~m}^{27}$. As the pit was filled, the southern part of the grave

27 Köhegyi 1980, 20. 


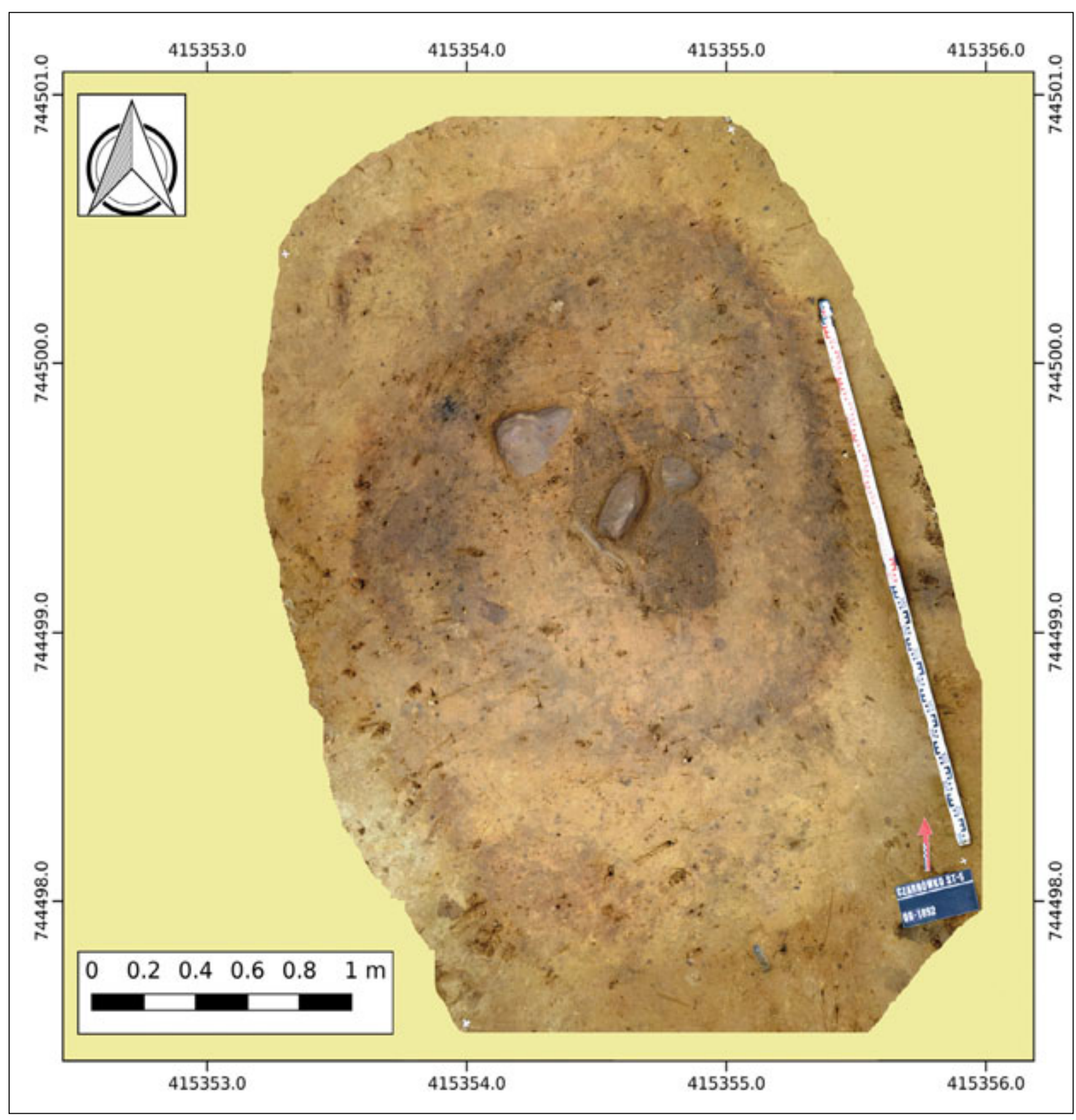

Fig. 3. Czarnówko, Lębork District. Cemetery of the Wielbark Culture. Example of an inhumation grave (1892/17) with a clearly visible so-called robbery trench. Photo K. Skóra, elaborated by J. Sikora.

was inaccessible and it remained undisturbed. In such a case, lower limbs remain in an undisturbed anatomical arrangement. The lack of coffins or logs closed from above may have caused a need for disturbing the entire surface of the grave pit.

\section{Tools}

No tools serving the purpose of „robberies” were discovered at Kowalewko. As demonstrated by discoveries from other periods, this set included wooden spades, testing tools such as iron rods, and poles or branches with hooklike terminals for extracting artefacts after the level of the skeleton had been reached ${ }^{28}$ (Fig. 5). The latter were especially useful for penetration of interiors of well-preserved and undamaged coffins. The use of iron rods is proven for Merovingian Period cemeteries. It can be supposed that the use of such tools allowed to assess the depth of the burial on the basis of reaching the empty space inside the coffin and to select the deepest burials for opening ${ }^{29}$.

28 Cf. Kümmel 2009, 135-136.

29 It is assumed that robbers of Merovingian cemeteries were able not only to assess the depth of grave pits but also to 


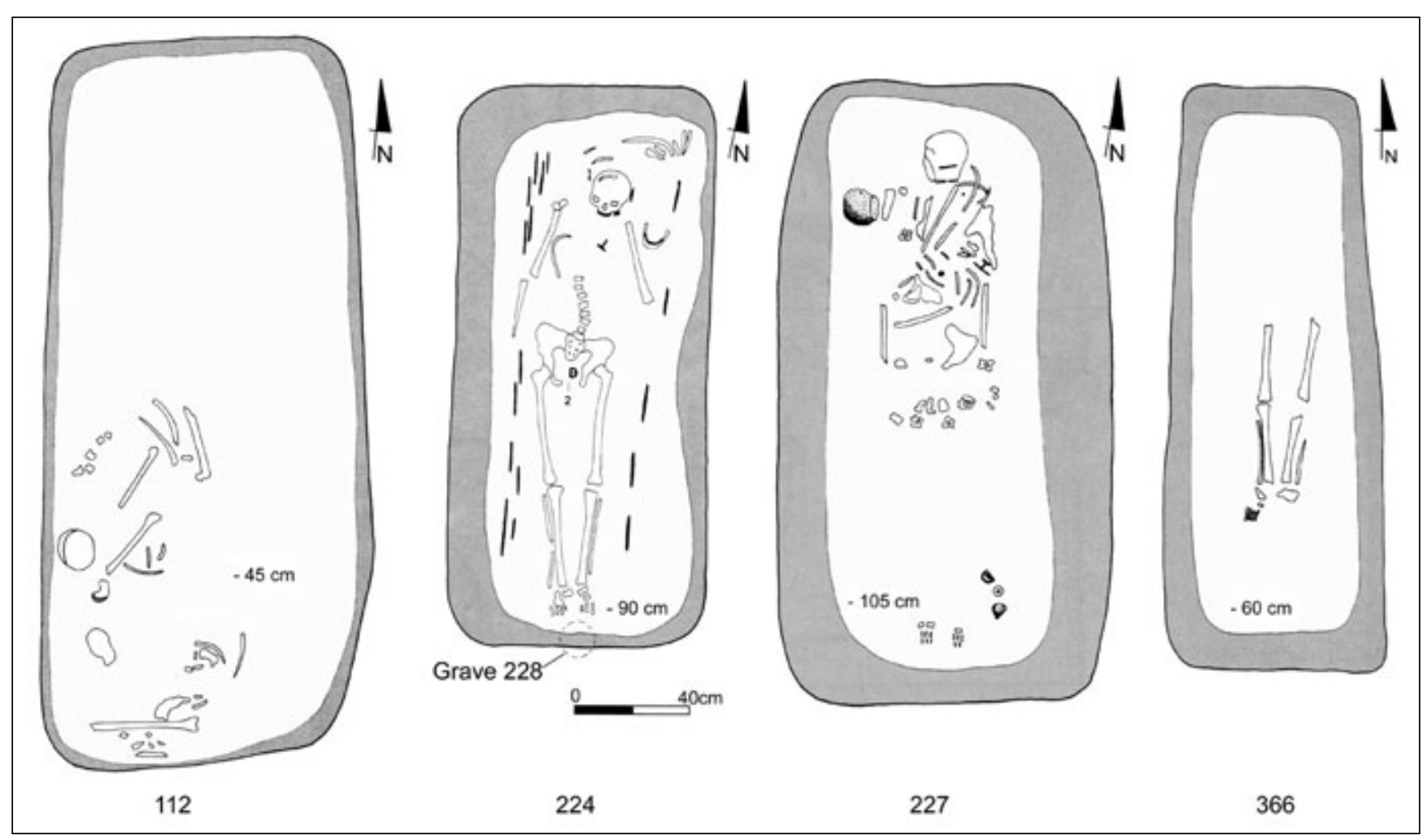

Fig. 4. Examples of degree of disturbance of grave pits at Kowalewko. After Skorupka 2001.

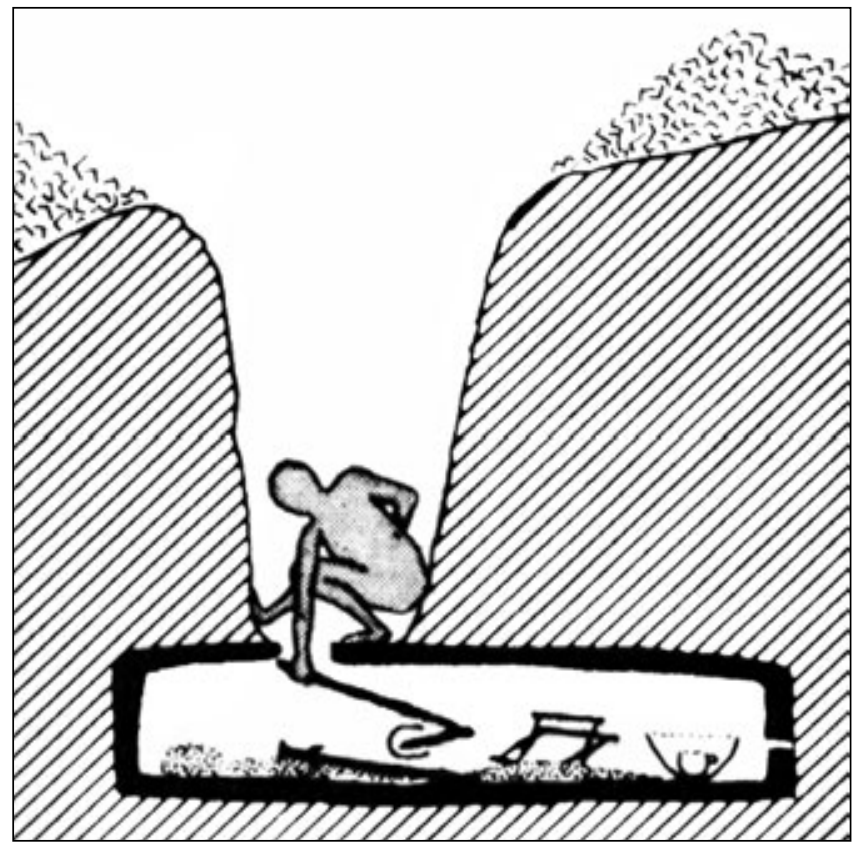

Fig. 5. Way of extraction of parts of grave furnishings from a coffin burial. After Thrane 1978, Abb. 5.

\section{Location within the cemetery}

Most graves with traces of manipulations are situated in the southern part of the site ${ }^{30}$ (Fig. 6). The central space is almost free of such cases, and some disturbances were

plan profitable actions by means of selecting graves, according to the sex of the dead - Sikora and Bofinger 2009, 341-342.

30 Skorupka 2001, Fig. 29. recorded in the northern zone. Such a situation may result from the fact that a majority of graves in the northern part are cremation ones, in which no traces of disturbances were found (which does not mean that they were absent ${ }^{31}$ ). Another reason is that the southern zone is related to richer burials, as they chiefly come from Phase B2/C1. This either demonstrates an excellent knowledge of „distribution” of precious artefacts and richer zones of the necropolis, or possibly suggests that robbers were led by sizes of overground marks (these from the last phases of use of the cemetery may have been more legible than earlier ones).

\section{When and which graves?}

Taking features identified by T. Skorupka as opened into consideration, it is possible to notice that this practice first of all concerned graves from Phase B2/C1. Due to the lack of grave furnishings it was not possible to identify the chronology of a few graves (cf. Table 3).

This analysis leads to a conclusion that the group of grave openers „preferred” graves from Phases B2/C1-C1, which were remarkable for the lavishness of their furnishings. On these grounds it can be assumed that:

- the group of grave openers had a knowledge on funeral rites and graves which guaranteed „profits”. Therefore, the originators acted contemporarily or in a short period of time after the cessation of use of this burial ground ${ }^{32}$.

31 Cf. Mączyńska 2011, 245.

32 Concerning precise location of trenches within grave pits - cf. Mączyńska 2011, 244, note 1227. 


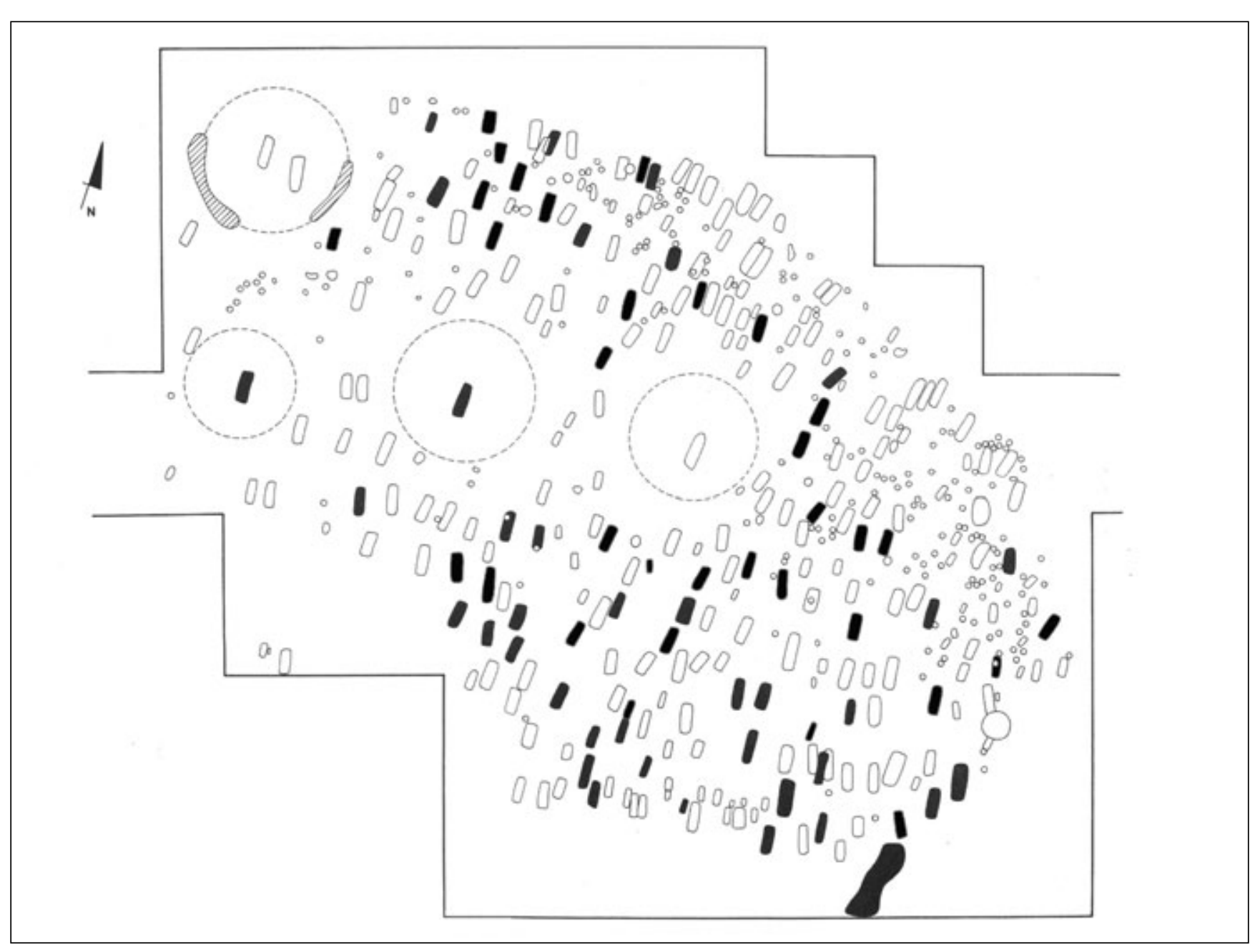

Fig. 6. Plan of the cemetery in Kowalewko - graves with traces of post-funeral intrusions. After Skorupka 2001. With additions by K. Skóra.

\begin{tabular}{|c|c|c|}
\hline Chronology of opened graves & $\mathrm{N}$ & $\%$ \\
\hline B2a & 5 & 7 \\
\hline B2b & 11 & 15.3 \\
\hline B2b-B2/C1 & 3 & 4.1 \\
\hline B2/C1 & 37 & 51.4 \\
\hline Roman Period & 16 & 22.2 \\
\hline$\Sigma$ & 72 & 100 \\
\hline
\end{tabular}

Table 3. Kowalewko. Chronological diversification of opened graves (based on data provided by T. Skorupka, with additions by K. Skóra).

- attention of the „robbers” focused on burials with still visible overground marks. These were at least stone structures, if not earthworks. Furthermore, graves from the last phases of use of the cemetery (B2/C1 to C1a) could be best identifiable.

What is of crucial importance for understanding of reasons behind grave opening is an assessment of the time or intrusion or a period between the origin of the grave and the intrusion into it. A sum of previous experiences concerning the assessment of the time of opening demonstrates that the following elements can be of help: tools ${ }^{33}$ or artefacts abandoned by participants in this event, stratigraphic premises - provided that features with well-datable chronology were dug into opened graves, or a rarely available opportunity to date these facts on the basis of historical sources $^{34}$. What is most often available for archaeology is an assessment of the chronological distance between these two events on the basis of the state of preservation of bone remains, grave furnishings and constructional parts of the grave, as well as the stratigraphic situation in the grave $\mathrm{pit}^{35}$.

The group of persons who were opening graves at Kowalewko did not leave traces enabling us to directly assess the time of their activity. All we can do is to assess the time between the burial and the intrusion on the basis of such premises as:

33 Coins abandoned in trenches or tools used for this purpose were left extremely rarely (axes, poles ended with hooks and spades; the latter are sometimes examined dendrochronologically - e.g., Billamboz and Neyses 1999).

34 Kümmel 2009, 147.

35 Kümmel 2009, 147. 
- traces of corrosion visible on bones, which are traces of removed metal artefacts

- arrangement of individual parts of skeletons, demonstrating that the intrusion in most cases took place after the decomposition of dead bodies, soft tissues and ligaments (however, there are exceptions to this).

The first premise enabled T. Skorupka to shift the moment of opening of graves in time to ,at least one year after the burial”. This assumption is based on traces of patina revealed on bones in places of missing copper alloy artefacts, e.g., fibulae on clavicles ${ }^{36}$. Of course, if an artefact is to leave traces on bones it must not only become covered with patina, but the dead body must also be reduced to the level at which the metal is in contact with the bone. Therefore, the ,at least one year” assessment is correct, but it would require specifying after an analysis of soil conditions in the cemetery and other factors (e.g., the depth of the grave pit), which influence the pace of decomposition of soft tissues.

Regrettably, an assessment of the time of origin of patina on bones in result of contact with a corroding artefact only suggests the time after which grave opening was possible. It is assumed that the process of passivation of artefacts made from copper alloys, which results in their covering with green patina does not commence directly after the burial. Its course depends, among others, on local factors, e.g., $\mathrm{pH}$ as well as moisture and permeability of substratum $^{37}$. Therefore, it can occur after at least one year ${ }^{38}$ or even after 10-30 years after the burial ${ }^{39}$. What also matters is the chemical composition of the alloy and its hardness ${ }^{40}$.

It seems impossible to point to the time of origin of discolouration on bone remains without additional analyses which would take conditions in which the artefact was deposited into consideration. Substratum properties, its chemical composition or $\mathrm{pH}$ level which are recorded nowadays are not identical with those in the past. One must also remember that present-day environmental factors, such as agricultural activities, have an evident impact on the state of preservation of contents of grave pits. Tests which were carried out in different types of soils demonstrated that the corrosion growth on copper alloy artefacts averagely proceeded at the pace of $0.05-4 \mu \mathrm{m}$ per annum - in feebly or averagely aggressive substratum - for the time of exposition under 20 years. Thereafter, the growth pace gradually slows down, approaching zero ${ }^{41}$. In a soil environment with more aggressive properties (e.g., acidic soils) this process advances at a much higher pace and the annual growth is up to $36 \mu \mathrm{m}$. In relation to the length of deposition of artefacts in the soil the time of covering with patina is relatively short

\footnotetext{
36 Skorupka 2008, 83.

37 Sprenger 1999, 44.

38 Cf. also Rittershofer 1987, 15, note 71.

39 Tylecote 1979, 366; Bertemes 1989, 128.

40 Tylecote 1979, 366.

41 Robbiola et al. 1998, 2086.
}

and is some dozen years. A period of several hundred years can result in the growth in the range of $0.5 \mathrm{~mm}^{42}$.

In places of contact between the metal and the body, after the skeletonisation it comes to a migration of salts to the bone. An increase in the toughness of bones in such a place or their „impregnation” may be a beneficial side effect ${ }^{43}$. Experimental research would certainly be of use - such research, however, has probably not been carried out yet.

Therefore, so far there are no precise assessments of the chronological distance of the origin of metal corrosion and its leaving traces on the skeleton in relation to factors which influence the pace of this process. It is perhaps impossible to go beyond generalised statements. The assessment of the time of decomposition of dead bodies and releasing of corrosion products by copper alloy artefacts is additionally rendered difficult by an aggressive nature of copper salts, which may accelerate the process of decomposition only in the place of contact with the dead body $^{44}$. In the remaining part the decomposition may proceed at a different, so to say, „own”, pace.

An issue which is of great significance for this discussion is an assessment of the duration of the skeletonisation process. In archaeological literature this time is assessed in various manners, with references to findings made by physical anthropologists or experiences from the field of forensic medicine. It seems, however, that at the level of individual cemeteries it would be relevant to undertake studies on how depositional and post-depositional factors influenced the state of preservation of bone remains ${ }^{45}$. It would be ideal if each burial were dealt with individually, even if due to unique individual traits, that is, abundance of adipose tissue, nature of bacterial flora or the season of year in which the burial took place (cf. Table 4).

Generally speaking, the decomposition of a dead body goes through various stages before the body is reduced to skeleton ${ }^{46}$. What is first affected are generally soft parts (alimentary system and circulatory system which are made from smooth tissues, then lungs, kidneys and bladder, brain and nervous tissues). Then go skeletal striated muscles, and the last ones are body covering and connective tissues. The latter are composed of protein collagen and are not prone to hydrolysis. Thus, its pace of decomposition is the slowest ${ }^{47}$.

It is believed on the basis of experimental research that three most important factors which shape the pace of decomposition are: temperature, insect activity and depth

\footnotetext{
42 Tylecote 1979, 366; Robbiola et al. 1998, 2086.

43 Sprenger 1999, 44.

${ }^{44}$ Cf. Sprenger 1999, 44.

45 Among exceptions it is possible to mention, among others, a work of this kind undertaken for the early medieval cemetery in Bodzia - Hildebrandt-Radke 2016.

46 Cf. Forbes 2008.

47 Gill-King 1997.
} 


\begin{tabular}{|c|c|c|}
\hline $\begin{array}{l}\text { CONDITION OF THE DEAD BODY BEFORE BURIAL } \\
\text { BODY WEIGHT } \\
\text { SHARE OF FATTY TISSUE } \\
\text { ACTIVITY OF INSECTS } \\
\text { BODY INTEGRITY (E.G., SHALLOW WOUNDS, DEEP WOUNDS } \\
\text { PENETRATING INTO BODY CAVITIES) } \\
\text { DEAD BODY DESICCATION } \\
\text { DEAD BODY EMBALMING } \\
\text { EXCARNATION } \\
\text { CLOTHS OR COVERING (KIND AND RAW MATERIAL) } \\
\text { BACTERIAL FLORA }\end{array}$ & & $\begin{array}{l}\text { CONDITION OF DEPOSITION } \\
\text { YEAR SEASON } \\
\text { ENVIRONMENT TEMPERATURE } \\
\text { SOIL PH } \\
\text { SUBSTRATUM MOISTURE } \\
\text { RAINFALLS } \\
\text { OXYGEN ACCESS } \\
\text { GRAVE CONSTRUCTION: } \\
\text { WIDTH, LENGTH AND DEPTH, BODY CONTAINERS (SIZE } \\
\text { AND RAW MATERIAL) } \\
\text { VOLUME OF EMPTY SPACE AROUND THE DEAD BODY } \\
\text { - COFFIN, TIMBER CHAMBER) }\end{array}$ \\
\hline & $\begin{array}{l}\text { FACTORS INFLUENCING } \\
\text { ACCELERATION OR SLOWING } \\
\text { DOWN OF THE DEAD BODY } \\
\text { DECOMPOSITION PROCESS }\end{array}$ & \\
\hline $\begin{array}{l}\text { ACTIVITY OF THE ANIMAL AND PLANT WORLD } \\
\text { MEGAFAUNA (E.G., SCAVENGERS) } \\
\text { MACROFAUNA (E.G., INSECTS) } \\
\text { MESO- AND MICROFAUNA ( }<2 \text { MM) } \\
\text { FLORA (PLANTS, FUNGI AND LOCAL SOIL BACTERIA) }\end{array}$ & & \begin{tabular}{|l} 
EROSION PROCESS IMPACT \\
WASHING OUT \\
SLIDING \\
SUBSIDENCE
\end{tabular} \\
\hline
\end{tabular}

Table 4. Factors influencing the pace of tissue decomposition and body disintegration. Based on Kümmel 2009, Fig. 3.35; Mann et al. 1990; Gill-King 1997; Forbes 2008.

\begin{tabular}{|c|c|}
\hline CONDITIONS AND ESTIMATED TIME OF DEAD BODY DECOMPOSITION & \\
\hline $\begin{array}{l}\text { BURIAL IN DRY SOIL }-3-4 \text { YEARS } \\
\text { BURIAL IN MOIST SOIL }- \text { RELATIVELY LONGER } \\
\text { MINIMUM TIME }-1-2 \text { WEEKS (STRONG DEPENDENCE ON EXTERNAL CONDITIONS) } \\
\text { IN A PECULIAR SITUATION, E.G., INSECT INVASION }-14-40 \text { DAYS } \\
\text { CLAYEY SUBSTRATUM - SEVERAL DECADES } \\
\text { SURFACE BURIAL }-2 \text { YEARS } \\
\text { BURIAL IN THE SOIL, WITH OXYGEN ACCESS, WATER PERMEABLE, DEPTH 1-3 M - 5-7 YEARS }\end{array}$ & Kümmel 2009. \\
\hline $\begin{array}{l}\text { DECOMPOSITION OF SOFT TISSUES - AT LEAST } 1 \text { YEAR } \\
\text { DECOMPOSITION OF TENDONS AND LIGAMENTS }-3 \text { YEARS ON AVERAGE }\end{array}$ & $\begin{array}{l}\text { Ritterhofer } 1987 \text {, } \\
14-15 \text {, note } 71 .\end{array}$ \\
\hline $\begin{array}{l}\text { ENVIRONMENT TEMPERATURE - 37.7 C, HIGH MOISTURE: SEVERAL WEEKS } \\
\text { ENVIRONMENT TEMPERATURE - } 18.3 \mathrm{C} \text { : MONTHS OR YEARS }\end{array}$ & Dix and Graham 2000, 19 \\
\hline $\begin{array}{l}\text { BURIAL AT A DEPTH OF 0.3-0.6 M - SEVERAL MONTHS UP TO ONE YEAR OR MORE } \\
\text { BURIAL AT A DEPTH OF 0.9-1.2 M - MANY YEARS }\end{array}$ & Mann et al. 1990. \\
\hline
\end{tabular}

Table 5. Averaged time of duration of the dead body decomposition process to the moment of skeletonisation - forensic medicine findings.

of the burial ${ }^{48}$. What slows down the decomposition are, among others, low temperature and greater depth of the grave. The decomposition is accelerated by strong aeration, access to ground waters, low depth of the burial and acid reaction of the soil. In especially acidic sands and gravels it comes to a complete decomposition, including bones. Burial traces are reduced to a dark silhouette of the body. This is believed to be an effect of reaction of phosphorus and manganese (products of body decomposition) with the soil environment ${ }^{49}$. These processes go at a slower pace in graves deeper than $1 \mathrm{~m}$ due to limitations in activities of insects and other invertebrates and scavengers, as well as due to lower temperature than in shallower graves ${ }^{50}$. All this data is of significance when assessing the integrity of bodies and the time of disturbance of their arrangement during grave opening.

At Kowalewko, in most burials which were considered „plundered” the bone arrangement demonstrates that this practice took place after a complete decomposition of soft tissues and ligaments, which are more durable. Thus, on 


\begin{tabular}{|c|c|c|c|c|c|c|c|c|}
\hline Age & Inf I & Inf II & Juv & Ad & Mat & Sen & $\begin{array}{c}\text { Adult or } \\
\text { unspecified } \\
\text { age }\end{array}$ & $\Sigma$ \\
\hline $\mathrm{F}$ & - & - & 2 & 14 & 6 & 3 & 2 & 27 \\
\hline $\mathrm{M}$ & - & - & 1 & 3 & 3 & 2 & 2 & 11 \\
\hline $\mathrm{N}$ & 5 & 5 & 5 & 7 & 2 & - & 10 & 34 \\
\hline$\Sigma$ & 5 & 5 & 8 & 24 & 11 & 5 & 14 & 72 \\
\hline
\end{tabular}

Table 6. Kowalewko - opened graves. Age and sex of the dead.
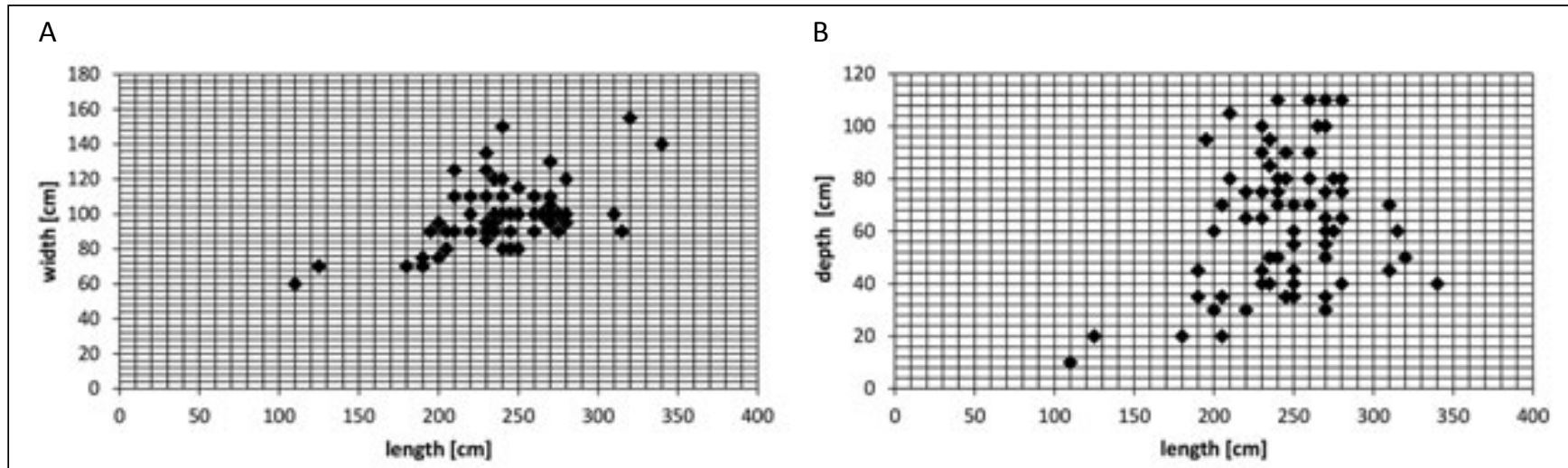

Fig. 7. Pit size parameters of opened graves at Kowalewko. A. length and width; B. length and depth. By K. Skóra.

the basis of the sum of the above conclusions one can only very generally assume an interval of a few years.

However, for a certain group of features there is a very different possibility. These are graves for which robbery is also assumed ${ }^{51}$, but in my opinion on the basis of some premises the reasons behind the grave opening are to be sought for elsewhere (Graves 284, 327, and 361). I will discuss this issue below.

\section{Whose graves were disturbed?}

We do not have information on the sex and age of buried persons for all burials which were considered opened. In this group there is a preponderance of women, especially of the adultus age class (Table 6). Such a result may first of all be an effect of mortality structure of the population from the cemetery in Kowalewko, as it is this age group of women that is the most numerous ${ }^{52}$.

In case the „robbery” was done by an alien community, a criterion of sex and age of the dead is of no significance. On the other hand, a certain role may have been played by the size of the grave pit, which was assessed on the basis of marks visible on the surface. The survival of such forms at Kowalewko could also be demonstrated by the fact that only a few graves belong to children. These pits are usually smaller and therefore their marks on the surface were in all probability also smaller. This observation could confirm a hypothesis concerning a short interval between the cessation of use of the necropolis and the activity of the ,robbers". On the other hand, the fact that some trenches were also led in other parts of the pits than their northern zones (therefore, the lack of precision) could imply that part of the graves was already not legible on the surface.

An opinion that „robbers” had a knowledge on the age, sex and position of the dead and they consciously omitted children's burials and poorly furnished graves in the discussed practice is expressed on the basis of analyses of some Migration Period and early medieval cemeteries $^{53}$, but also of earlier times ${ }^{54}$. According to anthropological assessments, remains of children were found in the opened Inhumation Graves 98, 359, 391, and 477. The fact of opening is demonstrated by the arrangement of artefacts in grave pits and by interspersing of bones ${ }^{55}$. Even if one assumes that the discussed phenomenon also concerns other graves of children (e.g., Graves 169, 331, 366, 387, 419, and 492), the share of the group of the community is lower as compared with adult persons whose graves fell prey to „robbery”. Thus, its significance in the discussed practice is also lower. No matter for what reasons graves were opened (e.g., material, ritual, belief or ideological

\footnotetext{
51 Skorupka 2008.

52 Skóra 2015a, Fig. 3.
} 
motivation), children seem to be a socially less important part of the population.

At Kowalewko, burials in pits which are smaller than $200 \mathrm{~cm}$ are in most cases anthropologically identified as belonging to children ${ }^{56}$. This, however, chiefly concerns the group of persons who died before completion of the age of 7. In this size range there are burials of adult persons, too, but they are of marginal significance. It is therefore possible to hypothetically assume that the object of interest of the „robbers” were only such graves in which they expected burials of adult persons, that is, burials containing richer grave goods than those of children. The length in the top of pits of graves which fell prey to „robbery” is generally between 200 and $300 \mathrm{~cm}$, with a few exceptions which go beyond this limit (cf. Fig. 7:A). On the other hand, a criterion of the pit depth was of no significance (Fig. 7:B).

\section{Way of treatment of dead bodies in the course of grave opening}

The grave intrusions which were revealed at Kowalewko in most cases led to a complete disturbance of the anatomical arrangement of dead bodies. This is possible in the case of complete skeletonisation. In such cases we notice disturbances in the place to which the trench led, but also in the remaining space of the grave pit, usually in its northern part. The lack of some bones is also an aftermath of this practice. These bones were either thrown outside, where it was easier to remove artefacts (e.g., bracelets) from them, or the use of a tool with a hook enabled the robbers to move grave goods together with bones within the coffin to one location, where it was easier to extract artefacts en masse. Sometimes no attempt at separating artefacts from bones was made, which could be explained by the fact that the robbers operated in a haste. Results of such action can be found in Grave 332 behind the head of the dead person (Fig. 8).

In the course of such actions numerous bones may have been broken, and the opening of the grave could only accelerate the process of their decomposition. Therefore, the theory that bones were acquired, no matter for what purposes, has no raison d'être in such circumstances. Pelvis bones, which were believed to have been the main focus of robbers ${ }^{57}$, must have fallen prey to destruction among the first ones, in case the trench was led into this part of the grave pit. Furthermore, the morphology of hip bones can also be responsible for their absence. Analogously to other flat bones (scapula, sternum, neurocranium vault bones), they are more prone to demineralisation, breaking and destruction ${ }^{58}$.

It is worth paying attention to a group of burials which were considered plundered, but which did not reveal traces

\footnotetext{
56 Skóra 2015a, Fig. 41

57 Żychliński 2015.

58 Gill-King 1997.
}

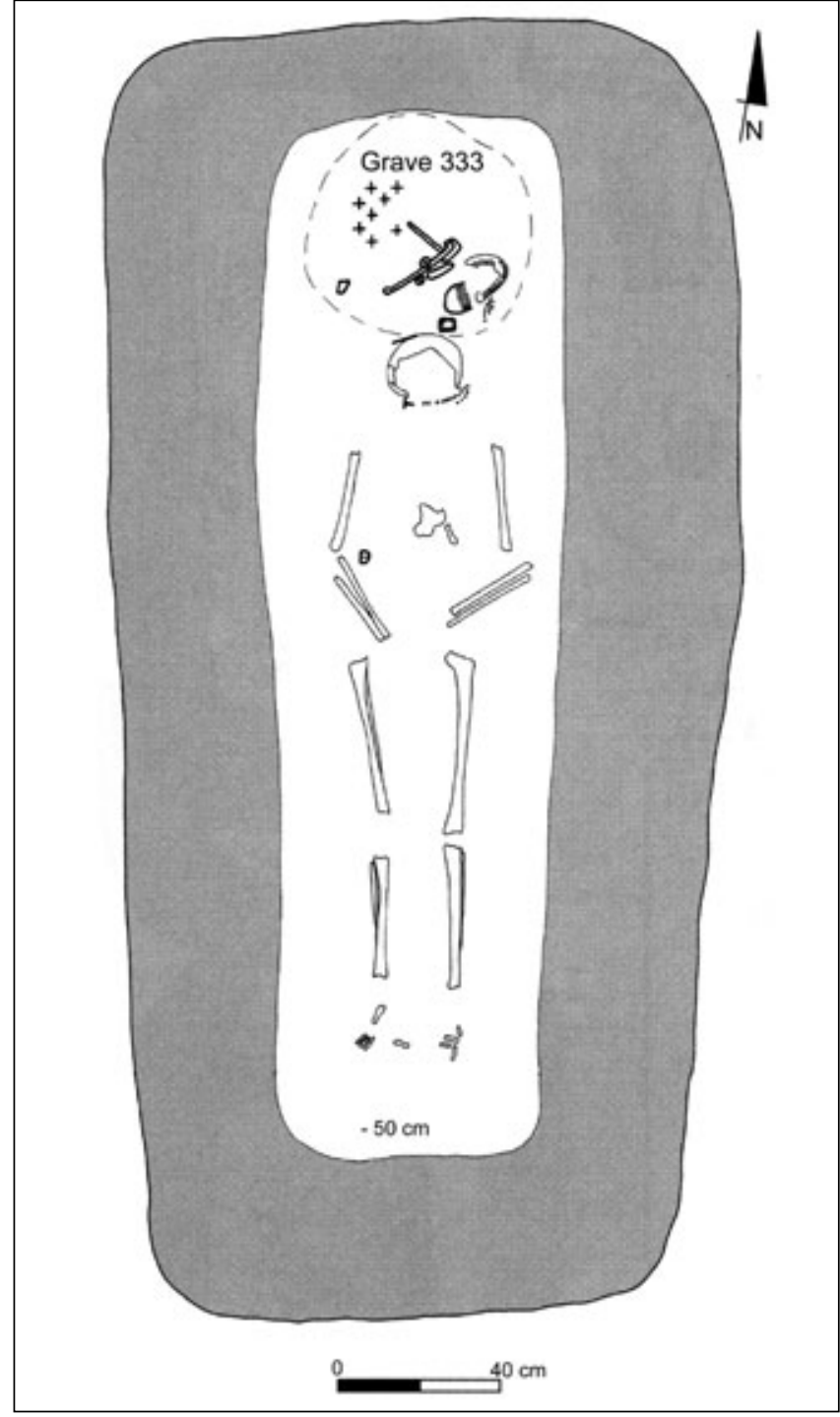

Fig. 8. Kowalewko, Grave 332. Concentration of artefacts and bones of the dead (including the mandible) in the northern part of the grave. After Skorupka 2001.

of a complete decomposition of soft tissues and ligaments at the moment of intrusion into the grave. In some features it was noted that the entire skull with the mandible was moved. This is possible only in case the process of decomposition of ligaments joining these skeleton parts was not completed. Such examples are sparse in comparison with the group of graves in which manipulations can be dated to the period after the natural process of separation of mandible from calvarium. Therefore, the theory on the use of „ritual practices” by robbers in order to protect themselves against the revenge of the dead should be considered again. According to T. Skorupka, features with traces of such practices are those in which the following traits were recorded: translocation of the skull to between the lower limbs - Grave 284, deposition of the skull on the chest - Grave 361, or turning the skull with the facial part down - Grave $327^{59}$ (Fig. 9).

59 Skorupka 2008, 83, Fig. 3. 


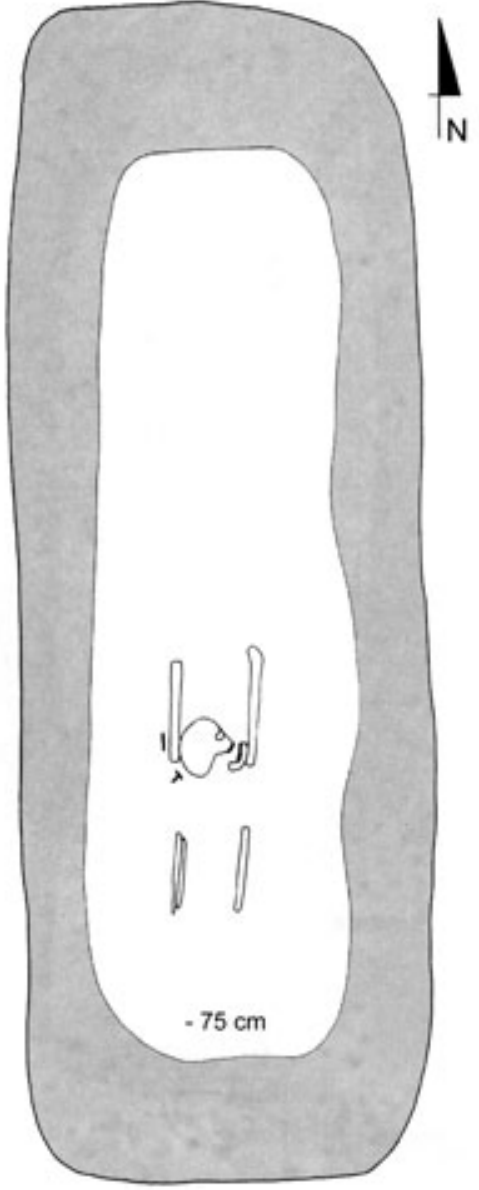

284

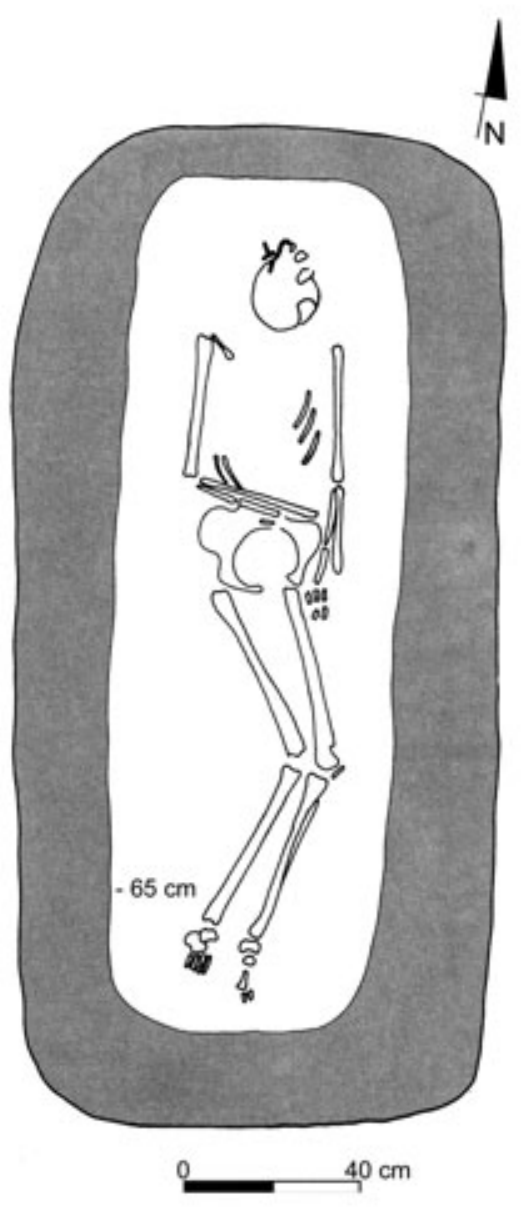

327

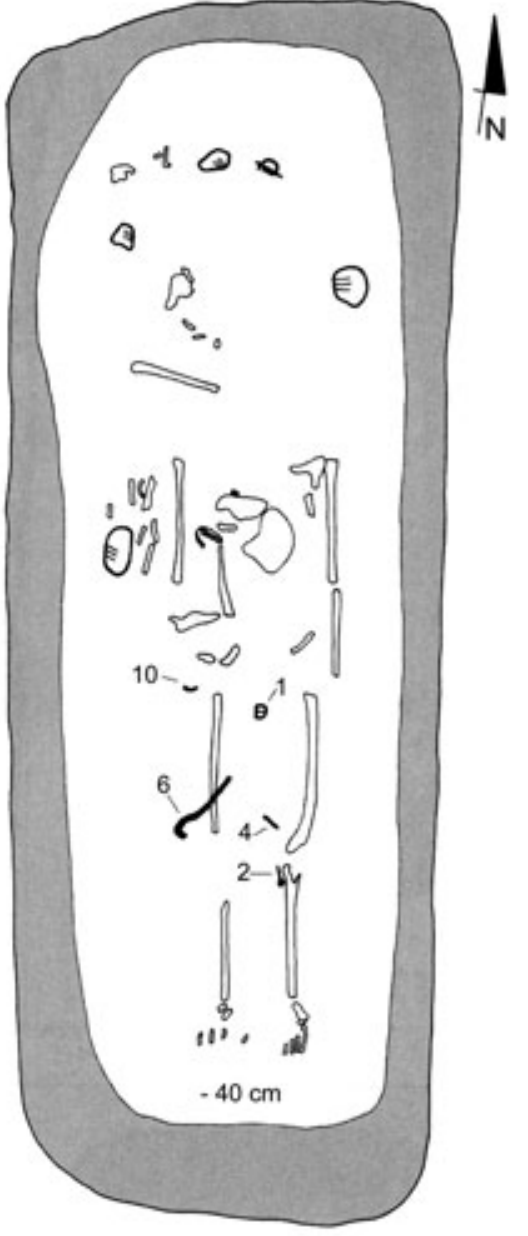

361

Fig. 9. Kowalewko. Examples of graves which were in all probability opened shortly (?) after the burial - translocation of the heads of the dead took place prior to complete skeletonisation. After Skorupka 2001.

Such practices are explained by a need for weakening the power of „robbed” dead persons. At the same time T. Skorupka assumed that these actions had been undertaken by the robbers and not by burial ceremony participants. What could also be of preventive nature was covering the grave with stones, „which were not necessarily an original marking of the grave" 60 .

Assuming a degree of integrity of the dead body in which cranium is still a unity, it should be supposed that a non-anatomical position of the head in the grave pit is a result of actions related either to decapitation (e.g., capital punishment) or to operations which took place after the burial but before the decomposition. In the latter case the cranium translocation may have been related to actions aimed at persons who were suspected of harmful post mortem acts. Therefore, originators were rather the community who used the necropolis than a group of strangers who entered the cemetery after the cessation of its use. Due to the fact that these burials bear traces of manipulations which

60 Skorupka 2008, 83-84. concerned not only the skulls, it can be assumed that these graves were opened twice, at different points of time.

\section{Problem of biritual burials}

Some words must be said on burials of mixed cremation-inhumation nature. This issue is also important for considerations concerning the sense of funeral and postfuneral rituals. At Kowalewko, in tops of a few inhumation graves a presence of cremation burials or burnt bones was found. The latter, as it is assumed, come from destroyed cremation burials (Table 7).

As the anthropological assessment of burnt bone remains is impossible, it is difficult to draw firm conclusions concerning the nature of funeral rites or to assess kinship relations between burnt and unburnt bones. It was only in one case (Grave 66) that anthropological analyses allowed to exclude a provenance of bone remains from one and the same person: these are namely bones of a child and of a man (Table 7). In the remaining features it was impossible to identify whether the burial concerned one and the same person or rather two dead persons who were buried according to two different rites. We can assume a biritual 


\begin{tabular}{|c|c|c|c|}
\hline Inhumation grave & Cremation grave & Remarks & Chronology \\
\hline $\begin{array}{l}\text { 236, } \\
\text { F?, matures }\end{array}$ & $\begin{array}{l}\text { 238, } \\
\text { Unspecified sex and age } \\
\text { „urn possibly destroyed in } \\
\text { the course of robbery of } \\
\text { the inhumation grave” }\end{array}$ & $\begin{array}{l}\text { Numerous burnt bones (referred } \\
\text { to as Grave 238), no outline } \\
\text { of a grave pit for the urn, } \\
\text { what remains of the urn are } \\
\text { sparse shards of its bottom }\end{array}$ & Roman Period and B2b \\
\hline $\begin{array}{c}\text { 332, } \\
\text { F, adultus }\end{array}$ & $\begin{array}{c}\text { 333, } \\
\text { Unspecified sex and age }\end{array}$ & $\begin{array}{l}\text { Burnt human bones (referred to } \\
\text { as Grave 333) in the „robbery” } \\
\text { trench together with translo- } \\
\text { cated and unburnt mandible }\end{array}$ & B2/C1 and B2 (?) \\
\hline $\begin{array}{c}\text { 334, } \\
\text { ?, adultus }\end{array}$ & $\begin{array}{c}335, \\
\text { Unspecified sex and age }\end{array}$ & $\begin{array}{l}\text { Burnt bones in the rob- } \\
\text { bery trench (referred to as } \\
\text { destroyed Grave 335) }\end{array}$ & B2/C1 and Roman Period \\
\hline $\begin{array}{l}\text { 349, } \\
\text { ?, juvenis }\end{array}$ & $\begin{array}{c}350, \\
\text { Unspecified sex and age }\end{array}$ & $\begin{array}{l}\text { Robbery trench in the } \mathrm{N} \text { part of } \\
\text { the pit, 140x } 80 \mathrm{~cm} \text { in size. The } \\
\text { trench contained pottery shards } \\
\text { (urn?), burnt human bones } \\
\text { (referred to as Urn Grave } 350 \text { ) }\end{array}$ & B2/C1 and B2b-B2/C1 \\
\hline $\begin{array}{c}\text { 66, } \\
\text { M?, adultus }\end{array}$ & infans I & $\begin{array}{c}\text { Burnt infans I human } \\
\text { bones - in the upper part } \\
\text { of a man’s skeleton }\end{array}$ & C1a \\
\hline $\begin{array}{c}224, \\
\text { F, aged } 20-25\end{array}$ & $\begin{array}{c}228 \\
\text { F, adultus }\end{array}$ & $\begin{array}{l}\text { Urn } 228 \text { dug into the } \mathrm{S} \\
\text { part of Grave Pit } 224\end{array}$ & $\mathrm{~B} 2 \mathrm{~b}$ and $\mathrm{B} 2 / \mathrm{C} 1$ \\
\hline $\begin{array}{c}241, \\
\text { unspecified sex and age }\end{array}$ & $\begin{array}{l}240, \\
\text { adult individual }\end{array}$ & $\begin{array}{l}\text { Urn } 240 \text { dug into the central } \\
\text { part of Grave Pit } 241 . \text { The } \\
\text { dead in the inhumation grave } \\
\text { was covered with charcoals }\end{array}$ & $\mathrm{B} 2 / \mathrm{C} 1$ and $\mathrm{B} 2 / \mathrm{C} 1$ \\
\hline $\begin{array}{c}253, \\
\text { unspecified sex and age }\end{array}$ & $\begin{array}{c}252, \\
\text { adultus? }\end{array}$ & $\begin{array}{l}\text { Urn } 252 \text { dug into the top of } \\
\text { Inhumation Grave } 253\end{array}$ & Roman Period and B2/C1 \\
\hline $\begin{array}{c}\text { 331, } \\
\text { Child, aged } 6\end{array}$ & $\begin{array}{c}\text { 309, } \\
\text { Unspecified sex and age }\end{array}$ & $\begin{array}{l}\text { Urn } 309 \text { dug into the } \\
\text { pit of Grave } 331\end{array}$ & $\mathrm{~B} 2 / \mathrm{C} 1$ and $\mathrm{B} 2 / \mathrm{C} 1$ \\
\hline
\end{tabular}

Table 7. Inhumation graves with „robbery” trenches and dug-in cremation burials. Based on Skorupka 2001.

nature of some of the aforementioned features (Table 7), that is, an extraction and cremation of unburnt parts of the skeleton (body?). However, we do not have enough data which would render this assumption probable. On the other hand, it is important that burnt remains which are interpreted as destroyed cremation graves chiefly come from fills (including trenches) of inhumation graves with traces of opening. In my opinion this fact is not a matter of accident and it would suggest other motivations behind intrusions into graves than merely „depriving” the dead of their grave goods. This matter, however, will remain unsolved - analogously to numerous other Wielbark Culture cemeteries where a poor state of preservation of bones renders their morphological or genetic assessment impossible ${ }^{61}$. It is certain that we cannot exclude that their presence is not accidental but is a manifestation of actions which were part of the grave opening practice ${ }^{62}$.

61 Cf. Skóra 2015b.

62 A custom of placing cremation graves in „robbery” trenches of inhumation graves was revealed at the Zealand cemetery
All these observations lead to a conclusion that there were different motivations and times of intrusion into graves. In my opinion there are two chronological perspectives which can be clearly seen in the group of features which are referred to as having fallen prey to „robberies”.

The first one would include actions of contemporary people. It cannot be excluded that there were kinship or social-ritual relations between the dead and grave disturbers. This group of features would include:

in Slusegaard. It is assumed that c. $150 \mathrm{AD}$ a new social group initiated a partial destruction of boat graves and other inhumation graves in result of a conflict and taking power from a previous privileged social group (whose members fulfilled religious functions). It must have come to opening of graves not due to an intention of acquiring artefacts (these were scattered in pits). It was done in order to secure themselves against the revenge of the dead from several past generations of ancestors and to symbolically manifest new political relations by local „cremation-people” - Crumlin-Pedersen 1995. 

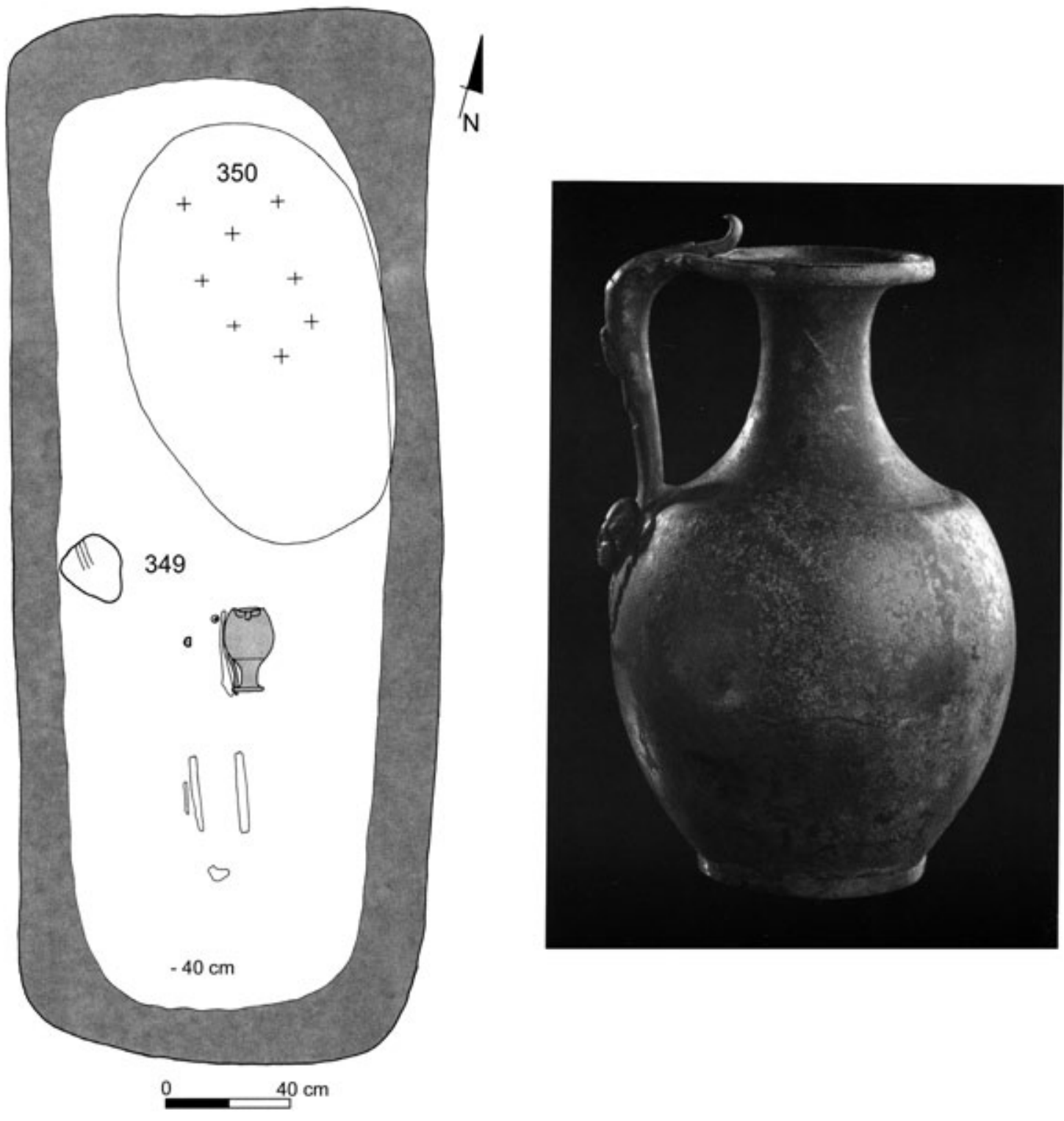

Fig. 10. Kowalewko. Graves 349 and 350. Inhumation grave with burnt human bones in the so-called robbery trench. After Skorupka 2001.

\begin{tabular}{|l|l|l|l|}
\hline & \multicolumn{2}{|c|}{ Chronological interval - from burial to intrusion } \\
\hline Reasons to open graves & $\begin{array}{c}\text { Contemporary } \\
\text { opening } \\
\text { Short interval } \\
\text { grave opening }\end{array}$ & $\begin{array}{c}\text { Very long time between } \\
\text { burial and opening, } \\
\text { an anonymous grave }\end{array}$ \\
\hline Symbolical: transfer and legitimisation of power & & & \\
\hline Religious, ancestor worship: recovery relics & & & \\
\hline Revenants & & & \\
\hline Sorcery & & & \\
\hline Protection: transfer to a different place & & & \\
\hline Looting & & & \\
\hline Accidental disturbance: e.g. through construction activity & & & \\
\hline Expiry dates of cemeteries & & & \\
\hline Individualistic behaviour & & & \\
\hline
\end{tabular}

Table 8. Proposal of reasons to open graves in relation to time which elapsed after the burial. Based on Aspöck 2015, 24. 


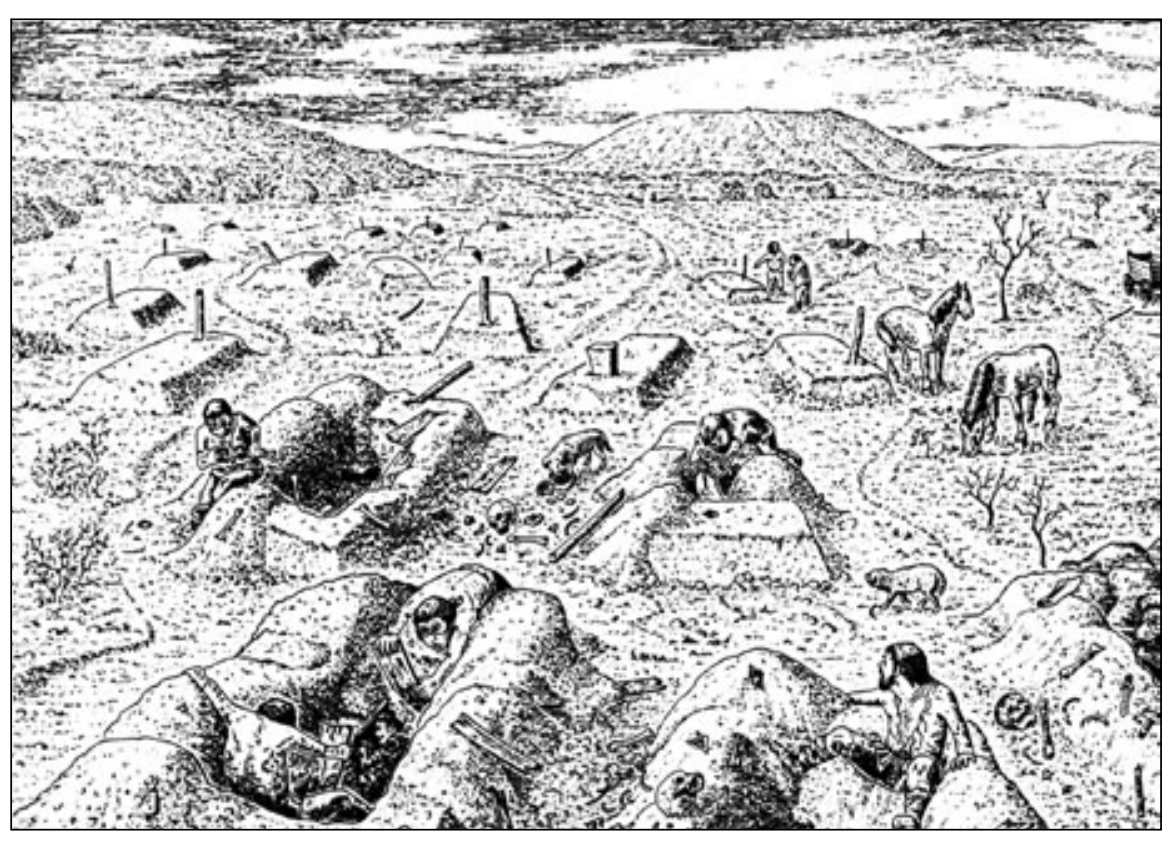

Fig. 11. Suggestive depiction of grave plundering in a Bronze Age cemetery. After Neugebauer 1994, Abb. 113.
- inhumation graves with traces of opening and with burnt human bone remains in „robbery” trenches

- inhumation graves with traces of opening shortly after the burial, that is, before the decomposition of the body. This is demonstrated by skulls which were translocated as a whole, together with mandibles. It cannot be excluded that such intrusions directly after the burial were more numerous at Kowalewko. However, on the basis of data acquired in the course of excavations it is not possible to point to other examples. Decapitation and separate deposition of the head into the grave would be testified to by the presence of cervical vertebrae which were separated from the remaining part of the backbone.

The latter perspective includes actions of probably alien persons, who selected the necropolis as a place of intrusions due to „robbery” motivations. It can also be assumed that persons from the same ethnic group came back to the necropolis and decided to take back goods given to the dead. However, strictly economic motivations of their actions should rather not be assumed. It cannot be excluded that certain kinds of artefacts may have been of other value than material.

T. Skorupka maintains that one should exclude „plundering” of the necropolis in Kowalewko by tribespeople inhabiting a contemporary settlement in the neighbourhood. It can rather be expected that the necropolis was „robbed” by aliens after the cessation of use of the cemetery, that is, in the end of the $1^{\text {st }}$ half of the $3^{\text {rd }} \mathrm{c}$. AD. Suspicions are rather directed against ,itinerant robbers” or a community of the Przeworsk Culture who once left northern Greater Poland and then returned there ${ }^{63}$. The mentioned „reconnaissance cut” in the southern part of the site would be a proof for the lack of knowledge on the layout of the cemetery and rules behind furnishing of the dead.
A mutual interethnic „grave robbery” is of course possible. M. Mączyńska assessed the cultural provenance of artefacts discovered in the ,hoard" from Łubiana in the territory of the Wielbark Culture. She suggested that these finds came from the border region of the Przeworsk and the Wielbark Cultures, most probably from northern Greater Poland, from the area to the south of the River Warta. Most artefacts are dated to Phases B2b-C1a. In this period the Wielbark Culture settlement was separated from the Przeworsk Culture settlement with an empty zone of c. $20 \mathrm{~km}^{64}$. In Phase C1b-C2 communities of the Wielbark Culture left Greater Poland and these territories were occupied by the Przeworsk Culture population ${ }^{65}$.

\section{What was the object of „robbery”?}

Generally, we do not have many premises to define the assortment of artefacts acquired from graves. The hoard from Łubiana in Pomerelia is informative in the case of graves which were opened in order to acquire raw materials, that is, due to economic reasons. Within the hoard, fibulae and fragments of bronze vessels are the most numerous. Less abundant are belt parts, ornaments, pins and needles, rivets and fittings, toilet utensils or fittings of drinking horns ${ }^{66}$. This assemblage of artefacts, however, represents the point of view of an artisan-founder.

\section{Abandoned artefacts}

A robbery nature of actions of the group of persons who opened the graves is supposed to be demonstrated by abandonment of unattractive parts of furnishing in trenches, as it is, e.g., the case with a corroded A V 96 fibula

63 Skorupka 2008, 83.

64 Mączyńska 2011, 246, Fig. 76.

65 Mączyńska 2011, 247.

66 Mączyńska 2011, 243. 
in Grave $353^{67}$. According to T. Skorupka, in case uninteresting and potentially useless artefacts were found, further extraction was sometimes stopped. The remaining artefacts, in spite of their attractiveness, remained in the grave (silver necklace, Grave 353). Some artefacts were broken, supposedly in the course of plundering (silver ornament from Grave $188^{68}$, fibula in Grave $285^{69}$ ).

Furthermore, some attractive artefacts were missed due to improperly led trenches. In such circumstances a bronze pitcher (Type Radnotti 77) evaded robbery (Fig. 10). It was discovered in the southern part of the grave pit at the level of the pelvis bone in Grave $349^{70}$. Some artefacts remained in place, in spite of being within the reach of the robbers. This may have been caused by difficulties in separating them from textiles or soft parts of the body which preserved their integrity.

In the light of archaeological research, the practice of grave opening in the Wielbark Culture first of all concerns graves from Phases B2c-B2/C171. However, this is not a final opinion. On the other hand, there are few premises which would allow for dating of the moment of burial opening. This intensified interest in features from these phases is perhaps related to abundance of grave furnishings in this period. However, it may turn out that such a relation is very superficial and the issue is more complex in its nature. In case it is proved that such actions were undertaken in the Antiquity during the period of use of individual necropoles, identification and interpretation of the habit of grave disturbance is of crucial importance for understanding relations between the world of the living and the world of the dead and for assessing the place of the dead in the social structure. On the one hand, it is believed that intrusion into graves which results in curtailing of grave furnishings and in disturbing of body integrity is a factor which renders a reconstruction of the social or demographic structure more difficult. On the other hand, these pieces of information on „losses” caused by inter- or post-funeral intrusions enable us to understand funeral customs of the past. It therefore seems significant to assess the extent of this phenomenon at the level of individual cemeteries. This will lead to identification of a model of such practices within the community of a given culture. There are strong premises to believe that apart from a usual practice of grave plundering done by groups of aliens we may be dealing with opening of graves of non-anonymous persons. According to E. Aspöck ${ }^{72}$, archaeological evidence is too ambivalent to enable us to relate such cases to specific reasons of grave opening which are known on the basis of ethnographic observations. This certainly does not mean that one should give up such attempts.

\section{Bibliography}

Andrzejowski J., Żórawska A., Biborski M., Kapla W. 2002. Grób 122 z cmentarzyska kultury wielbarskiej w Jartyporach na Podlasiu. Nowe materiaty do badań nad obrzadkiem pogrzebowym w gockim kręu kulturowym. In: M. Karczewska, M. Karczewski (eds.), Badania archeologiczne w Polsce pótnocno-wschodniej i na zachodniej Białorusi w latach 2000-2001. Materiały z konferencji. Białystok, 253-263.

Aspöck E. 2011. Past 'Disturbances' of Graves as a Source: Taphonomy and Interpretation of Reopended Early Medieval Inhumation Graves at Brunn am Gebirge (Austria) and Winnall II (England). „Oxford Journal of Archaeology” 30 (3), $299-324$.

Aspöck E. 2015. Cross-cultural interpretations and archaeological context. A reopened early bronze age grave in Weiden am See, Austria. In: L. Gardeła, K. Kajkowski (eds.), Kończyny, kości i wtórnie otwarte groby w dawnych kulturach. Limbs, bones, and reopened graves in past societies. Międzynarodowe Spotkania Interdyscyplinarne „Motywy przez wieki" 2. Bytów, 21-46.

Bertemes F. 1989. Das frühbronzezeitliche Gräberfeld von Gemeinlebarn. Kulturhistorische und paläometallurgische Studien. Text und Katalog. Saarbrücker Beiträge zur Altertumskunde 45, Bonn: Habelt.

Billamboz A., Neyses M. 1999. Das Fürstengrab von Villingen-Magdalenenberg im Jahrringkalender der Hallstattzeit. In: K. Springer, Der Magdalenenberg bei Villingen. Das Fürstengrabhügel des 7. vorchristlichen Jahrhunderts. Führer zu Archäologischen Denkmälern in Baden-Württemberg 5. $2^{\text {nd }}$ ed. Stuttgart: Theiss, 91-109.

Crumlin-Pedersen O. 1995. Boat-burials at Slusegaard and the Interpretation of the Boat-grave Custom. In: O. Crumlin-Pedersen, B. Munch Thye (eds.), The Ship as Symbol in Prehistoric and Medieval Scandinavia. Papers from an

67 Skorupka 2001, 94.

68 Skorupka 2001, 57.

69 Skorupka 2001, 79.

70 Skorupka 2001, Table 104.

71 On the basis of the chronology of the artefacts from the hoard in Lubiana it can be assumed that graves from Phases B2b-C1a were most often disturbed - Mączyńska 2011, 244.

72 Aspöck 2015, 40. 
International Research Seminar at the Danish National Museum, Copenhagen, 5th-7th May 1994. Publications from the National Museum. Studies in Archaeology\&History 1, Copenhagen, 87-99.

Dix J., Graham M. 2000. Time of Death, Decomposition and Identification. An Atlas, CRC Press, Boca Raton, London, New York, Washington D.C.

Forbes S. L. 2008. Decomposition Chemistry in a Burial Environment. In: M. Tibbett, D. O. Carter (eds.), Soil Analysis in Forensic Taphonomy. Chemical and Biological Effects of Buried Human Remains. CRC Press, Boca Raton, London, New York, 203-223.

Gill-King H. 1997. Chemical and Ultrastructural Aspects of Decomposition. In: W. D. Haglund, M. H. Sorg (eds.), Forensic Taphonomy. The Postmortem Fate of Human Remains. CRC Press, Boca Raton, London, New York, Washington.

Hildebrandt-Radke I. 2016. Wpływ procesów depozycyjnych i podepozycyjnych na stan zachowania pochówków na cmentarzysku szkieletowym w Bodzi. In: A. Buko (ed.), Bodzia. Elitarny cmentarz z początków państwa polskiego. Warszawa, 59-65.

Köhegyi M. 1980. Sarmatenzeitliche Grabberaubung in Ungarn. In: H. Wolfram, F. Daim (eds.), Die Völker an der mittleren und unteren Donau im fünften und sechsten Jahrhundert. Berichte des Symposions der Kommission für Frühmittelalterforschung, 24. bis 27. Oktober 1978, Stift Zwettl, Niederösterreich. Veröffentlichungen der Kommission für Frühmittelalterforschung 4. Wien, 19-22.

Kokowski A. 2007. Goci. Od Skandzy do Campi Gothorum (od Skandynawii do Pólwyspu Iberyjskiego). Warszawa.

Kümmel Ch. 2009. Ur- und frühgeschichtlicher Grabraub. Archäologische Interpretation und kulturanthropologische Erklärung. Tübinger Schriften zur Ur- und Frühgeschichtlichen Archäologie 9, Münster.

Mann R. W., Bass W. M., Meadows L. 1990. Time Since Death and Decomposition of the Human Body: Variables and Observations in Case and Experimental Field Studies. „Journal of Forensic Sciences, JFSCA” 35 (1), 103-111.

Mączyńska M. 2011. Der frühvölkerwanderungszeitliche Hortfund aus Lubiana, Kreis Kościerzyna (Pommern). „Bericht der Römisch-Germanischen Kommission" 90, 2009, 7-482.

Neugebauer J. W. 1994. Zum Grabraub in der Frühbronzezeit Niederösterreichs. In: K. Schmotz (ed.), Vorträge 12. Niederbayerischer Archäologentag. Buch am Erlbach, 109-147.

Rittershofer K.-F. 1987. Graubraub in der Bronzezeit [Vortrag zur Jahressitzung 1987 der Römisch-Germanischen Kommission]. „Bericht der Römisch-Germanischen Kommission” 68, 5-23.

Robbiola L., Blengino J.-M., Fiaud C. 1998. Morphology and Mechanisms of Formation of Natural Patinas on Archaeological Cu-Sn Alloys. „Corrosion Science” 40 (12), 2083-2111.

Schuster J. 2010. Lübsow. Älterkaiserzeitliche Fürstengräber im nördlichen Mitteleuropa. Bonner Beiträge zur Vor- und Frühgeschichtlichen Archäologie 12, Bonn.

Schuster J. 2014. Złoty wiek - Czarnówko w okresie wpływów rzymskich $i$ w okresie wędrówek ludów. In: J. Andrzejowski, J. Schuster (eds.), Okruch złota w popiele ogniska. Starożytne nekropole w Czarnówku i ich tajemnice. Lębork, Warszawa, 53-89.

Sikora P., Bofinger J. 2009. Metody rabunku, metody eksploracji - wczesnomerowińskie cmentarzysko w Remseck/Pattonville Lk. Ludwigsburg. In: W. Dzieduszycki, J. Wrzesiński (eds.), Metody. Źródła. Dokumentacja. Funeralia Lednickie 11, Poznań, 339-344.

Skorupka T. 2000. Atypowe pochówki na cmentarzysku w Kowalewku. In: J. Wrzesiński (ed.), Czarownice. Funeralia Lednickie 2, Wrocław, Sobótka, 91-99.

Skorupka T. 2001. Kowalewko. Cmentarzysko birytualne ludności kultury wielbarskiej (od połowy I w. n.e. do początku III w. n.e.). Archeologiczne badania ratownicze wzdłuż trasy gazociągu tranzytowego 2: Wielkopolska 3, Poznań.

Skorupka T. 2008. Atypowe pochówki na cmentarzysku w Kowalewku. In: J. Wrzesiński (ed.), Czarownice. Funeralia Lednickie 2, Edition 2, Poznań, 79-85.

Skóra K. 2014. Trup nieobecny?... czyli o brakujących szczątkach kostnych w grobach kultury wielbarskiej. In: T. Kurasiński, K. Skóra (eds.), Grób w przestrzeni, przestrzeń w grobie. Przestrzenne uwarunkowania w dawnej obrzędowości pogrzebowej. „Acta Archaeologica Lodziensia” 60, Łódź, 45-68.

Skóra K. 2015a. Struktura społeczna ludności kultury wielbarskiej. Łódź.

Skóra K. 2015b. Biritual burials of the Wielbark Culture - introductory remarks. In: L. Gardeła, K. Kajkowski (eds.), Konczyny, kości i wtórnie otwarte groby w dawnych kulturach. Limbs, bones, and reopened graves in past societies. Międzynarodowe Spotkania Interdyscyplinarne „Motywy przez wieki” 2. Bytów, 85-122.

Skóra K. 2017. The sitting (?) dead - an attempt at assessing discoveries from cemeteries of the Wielbark Culture. In: J. Andrzejowski, C. von Carnap-Bornheim, A. Cieśliński, B. Kontny (eds.), Orbis Barbarorum. Studia ad archaeologiam Germanorum et Baltorum temporibus Imperii Romani pertinentia Adalberto Nowakowski dedicate. Warszawa, Schleswig, 537-548. 
Sprenger S. 1999. Zur Bedeutung des Grabraubes für sozioarchäologische Gräberfeldanalysen. Eine Untersuchung am frühbronzezeitlichen Gräberfeld Franzhausen I, Niederösterreich. Fundberichte aus Österreich, Materialheft A7, Wien.

Tempelmann-Mączyńska M. 1989. Totenfurcht und Totenglauben bei den Germanen im 4. bis 7. Jahrhundert n. Chr. aufgrund der sog. Sonderbestattungen und des Grabraubs.,,Zeitschrift der Savigny-Stiftung für Rechtsgeschichte” 119, 274-283.

Tempelmann-Mączyńska M. 1992. „Specyficzne” pochówki kultury wielbarskiej. „Acta Universitatis Lodziensis. Folia Archaeologica” 16, 191-199.

Thrane H. 1978. Beispiel für Grabraub aus der Bronzezeit Dänemarks. In: H. Jankuhn, H. Nehlsen, H. Roth (eds.), Zum Grabfrevel in vor- und frühgeschichtlicher Zeit. Untersuchungen zu Grabraub und „haugbrot” in Mittel- und Nordeuropa. Bericht über ein Kolloquium der Kommission für die Altertumskunde Mittel- und Nordeuropas vom 14 . bis. 16. Februar 1977. Abhandlungen der Akademie der Wissenschaften in Göttingen, Göttingen, 9-17.

Tylecote R. F. 1979. The effect of soil conditions on the long-term corrosion of buried tin bronzes and copper. „Journal of Archeological Science" 6, 345-368.

Vaday A. 2015. The langobard cemetery at Ménföcsanak. „Antaeus” 33, 163-242.

Żychliński D. 2014. Obrządek pogrzebowy ludności kultury przeworskiej i wielbarskiej w Wielkopolsce. Zielona Góra, Gniezno.

Żychliński D. 2015. Reopening Graves in Pre-roman and Roman period in Greater Poland - a (Re)interpretation. In: L. Gardeła, K. Kajkowski (eds.), Kończyny, kości i wtórnie otwarte groby w dawnych kulturach. Limbs, bones, and reopened graves in past societies. Międzynarodowe Spotkania Interdyscyplinarne „Motywy przez wieki” 2. Bytów, 47-84.

\section{Streszczenie}

\section{Otwieranie grobów na cmentarzysku kultury wielbarskiej w Kowalewku. Analiza wstępna}

Zjawisko otwierania, czy jak się częściej określa - wskazując jednocześnie na charakter ingerencji - „rabowania” grobów kultury wielbarskiej jest powszechnie znane, czego wyrazem jest miejsce w literaturze przedmiotu. W artykule tytułowy problem przeanalizowano na przykładzie cmentarzyska kultury wielbarskiej w Kowalewku. Materiały pozyskane z tego właśnie stanowiska, ze względu na pełne rozpoznanie wykopaliskowe i dobry stan zachowania szkieletów mogą stanowić podstawę do opisania praktyki otwierania grobów we wczesnym i środkowym okresie rzymskim. Omówiono zatem dotychczasowe propozycje interpretacji i zaproponowano nowe ujęcie problemu. Artykuł ten nie wyjaśni wszystkich wątpliwości wiążących się z tytułową kwestią, a stanowi jedynie próbę zwrócenia uwagi na kilka aspektów z nią związanych. To jest istotne dla ocenienia celu ingerencji grobowej, który zawiera się w pytaniach: kto, kiedy i jak?

$\mathrm{Z}$ analizy materiałów z Kowalewka wyłania się wniosek o różnych motywach i czasie ingerencji grobowych. W grupie obiektów, które określane są jako objęte „rabunkiem”, rysują się dwie perspektywy czasowe. Pierwsza z nich obejmowałaby działania osób współczesnych. Do tej grupy obiektów należałyby: groby inhumacyjne ze śladami otwarcia i z przepalonymi ludzkimi szczątkami kostnymi we wkopach „,rabunkowych” oraz groby inhumacyjne ze śladami otwarcia w krótkim czasie po pogrzebie, a więc przed dekompozycją zwłok, o czym świadczą czaszki, przemieszczone w całości, a więc razem z żuchwami.

Druga z perspektyw obejmuje działania osób najprawdopodobniej obcych, które obrały sobie nekropolię jako miejsce ingerencji z powodów „rabunkowych”. Można założyć także powrót na nekropolię osób z tej samej grupy etnicznej, która postanowiła odebrać podarowane zmarłym dobra. Raczej nie należałoby przypisywać ich działaniom motywów jedynie stricte ekonomicznych. Nie można wykluczyć, że określone rodzaje przedmiotów mogły mieć inną niż materialna wartość.

Praktyka otwierania grobów w świetle badań archeologicznych w kulturze wielbarskiej dotyczy przede wszystkim grobów z faz B2b-C1a, aczkolwiek nie jest to ostateczny głos w dyskusji. Natomiast przesłanek pozwalających na wydatowanie momentu otwarcia pochówku mamy niewiele. To wzmożone zainteresowanie obiektami z tych faz pozostaje zapewne w relacji z obfitością wyposażenia grobowego w tym czasie. Jednak może okazać się, że jest to tylko powierzchowna asocjacja, a problem jest bardziej złożony w swej istocie. Identyfikacja i interpretacja zwyczaju naruszania grobów w przypadku udowodnienia, że działania te były podejmowane w starożytności w okresie użytkowania poszczególnych nekropoli, ma kluczowe znaczenie dla zrozumienia relacji łączących świat żywych i zmarłych oraz określenia miejsca zmarłych w strukturze społecznej. Wiele wskazuje na to, że oprócz zwykłego procederu rabowania przez grupy obcych mamy do czynienia z otwieraniem grobów osób nieanonimowych. Kwestia ta wymaga jeszcze dalszych studiów i porównania na szerszym tle kulturowym. 